\title{
THE ELITE MARATHON RUNNER: PROBLEMS DURING AND AFTER COMPETITION
}

\author{
P. HÖLMICH, E. DARRE, F. JAHNSEN and T. HARTVIG-JENSEN \\ The Wonderful Copenhagen Marathon 1986 Study Group
}

\section{ABSTRACT}

Two questionnaires were given to the participants of the Danish national marathon championship to obtain information on health, training habits, previous injuries and the medical problems sustained during and after the competition. All 60 participants replied to both questionnaires.

The elite runner is training between $90-150 \mathrm{~km}$ per week, using one daily training session. He is generally careful about stretching and warming up and down. Forty-three per cent of runners sustained injuries in the last year that prevented them from training, but only $3 \%$ needed to stay off work. The most common reasons for not completing the race were exhaustion and injuries to the lower extremities. Sixty-one per cent of the runners who did not drink at all refreshment stations dropped out, whereas only $27 \%$ of those who did dropped out.

There was no difference in relation to results or medical problems between the group who used a special diet before the run and those who did not. The major medical problems were gastrointestinal disturbances, skin lesions and pain or cramps in the lower extremities. No serious injuries were reported.

Key words: Marathon, Training, Injuries

\section{INTRODUCTION}

Long distance running and especially marathon running has become increasingly popular during the last 15 years. A great number of marathon events is arranged every year and a large group of elite marathon runners has developed. They represent a category of very dedicated and hard working athletes who are training at the limit of their physical capacity.

The aim of the present study was to describe this group of marathon runners, their health, training habits and previous injuries. Additionally we wanted to register the incidence of medical problems during and after a demanding competition.

\section{MATERIALS AND METHODS}

The Danish national marathon championship for men 1986 took place in connection with the Wonderful Copenhagen Marathon, which is an open entry competition. The entry criteria for the championship was a previous marathon result better than 2.40 in 1985 or 1986 . A few dispensations were given to otherwise qualifed debutants.

The race started in the city of Copenhagen on the 17th May at 3 p.m. The weather was a little cloudy with a temperature of $16^{\circ} \mathrm{C}$, a wind speed of $6 \mathrm{~m} / \mathrm{sec}$ and a humidity of $45 \%$ at the start of the race and $37 \%$ at 5 p.m. Along the route refreshment points with available fluids were placed every $5 \mathrm{~km}$. The fluids were either water or a commercial product with carbohydrate and salts.

Sixty runners participated in the championship. The winner's time was 2.15.04. Before the race all the participants were given two questionnaires, one concerning information on health, training and previous experience, the other concerning the results and the medical problems during and after the race. All 60 elite marathon runners replied to both questionnaires.

\section{RESULTS}

The median age of the 60 runners was 28 years (range 18 to 51). Four of the runners had not previously run a marathon,

Address for correspondence:

Per Hölmich, MD

Gersonsvej 12

DK-2900 Hellerup

Denmark but generally they were experienced runners and $50 \%$ had been running for more than 6 years and only 3 runners less than 2 years. Two-thirds of the runners were running between 90 and $150 \mathrm{~km}$ per week (Table I), using one daily training session. Five runners trained more than $150 \mathrm{~km}$ per week and twice a day.

\section{TABLE I}

Weekly training distance among the participants of the 1986 Danish national marathon championship for men.

\begin{tabular}{lr}
\hline$k m$ per week & Number \\
\hline $31-60$ & 2 \\
$61-90$ & 12 \\
$91-120$ & 20 \\
$121-150$ & 21 \\
$151-180$ & 4 \\
$181-210$ & 1 \\
\hline Total & 60 \\
\hline
\end{tabular}

Ninety-five per cent of the participants warm up before competition and $42 \%$ before training (Table II). Sixty per cent warm down after competition as well as after training. Eighty-five per cent perform stretching exercises regularly. Protection of the skin with vaseline, plaster etc. was used to a smaller degree (Table II). None of the 12 runners who used foot protection had blisters, in comparison $31 \%$ of the remaining 48 runners had blisters.

\section{TABLE II}

Methods aimed at injury prevention among the participants of the 1986 Danish national marathon championship for men.

\begin{tabular}{lc}
\hline & Number \\
\hline Warming up before training & 25 \\
Warming up before competition & 57 \\
Warming down after training & 36 \\
Warming down after competition & 37 \\
Stretching & 51 \\
Special protection of the feet & 12 \\
$\quad$ the nipples & 17 \\
& the axillas \\
& 7 \\
&
\end{tabular}


Thirty of the runners used a special diet in the days before the competition, of these 11 used the classical high carbohydrate diet (Ahlborg et al, 1976; Bergstrøm et al, 1967; Hultman, 1967; Ivy et al, 1980).

A comparison between the grop who used a special diet before the competition and the rest of the runners showed no differences either in results or in the drop-out rate (Table III). The elite marathon runner is characterised by a low body weight. Fig. 1 shows graphically the divergence from the ideal weight as it is described by Natvig (1980).

\section{TABLE III}

Diet eaten before the Danish national marathon championship 1986 for men in relation to accomplished results.

\begin{tabular}{lcc}
\hline Result & Special diet & Ordinary diet \\
\hline 2.20 & 1 & 0 \\
$2.20-2.30$ & 3 & 3 \\
$2.30-2.40$ & 6 & 7 \\
$2.40-2.50$ & 2 & 4 \\
$2.50-3.00$ & 2 & 2 \\
$3.00-3.10$ & 1 & 0 \\
$3.10-3.20$ & 0 & 1 \\
Dropped out & 15 & 13 \\
\hline Total & 30 & 30 \\
\hline
\end{tabular}

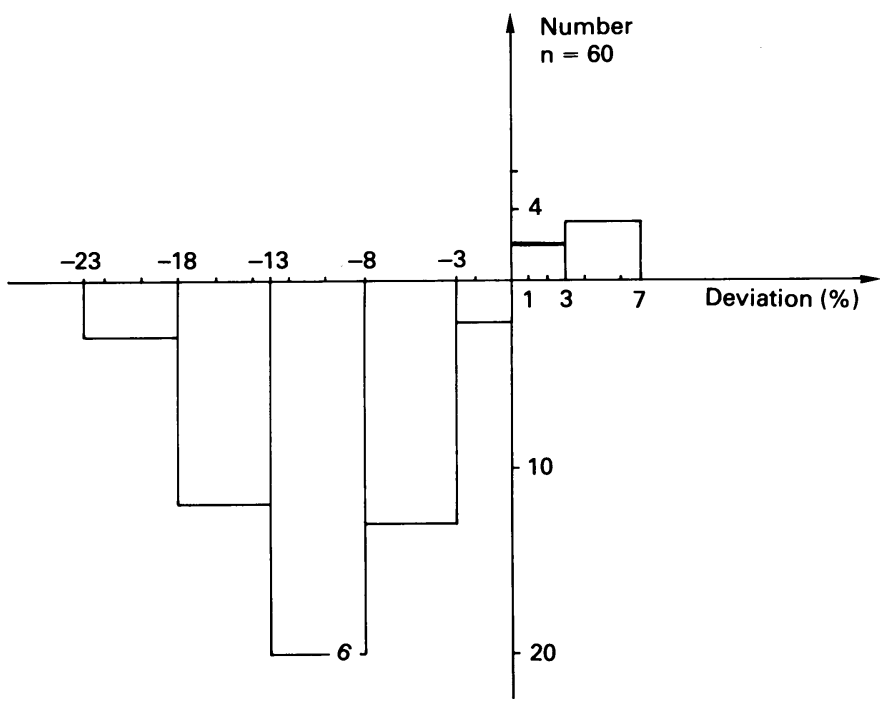

Fig. 1: The deviation from the ideal weight among the participants of the Danish national marathon championship 1986 for men.

Of the 60 runners two suffered from asthma and one from arterial hypertension. Two of these used daily medication, one used prednisone and one used a $\beta_{2}$-antagonist (metoprolol). Eight runners had been ill in the month preceding the race. Eight were regular smokers.

In the past year 26 runners $(43 \%)$ had been injured, preventing them from training. Only two had injuries preventing them from attending work.

Thirty-one completed the race, 26 did not complete and 3 did not participate because of illness on the day of the race. Six runners had run a marathon in the preceding five weeks, of these only one finished. Of the four marathon debutants three completed. The reasons for not completing the run are shown in Table IV. The group called "tactical reasons" is
TABLE IV

Reasons for dropping out of the Danish national marathon championship 1986 for men.

\begin{tabular}{lc}
\hline Reason & Number \\
\hline Exhaustion & 11 \\
Injury to lower extremities & 7 \\
Gastrointestinal problems & 2 \\
Tactical reasons & 5 \\
Others & 1 \\
Did not participate & 3 \\
\hline Total & 29 \\
\hline
\end{tabular}

defined as runners who made the decision to drop out before they started, using the race as training, or runners who dropped out because a new personal record was unattainable. The drop-out rate for the open entry race with 2514 participants was $15.6 \%$.

Along the route 26 runners drank fluid at every opportunity, of these $27 \%$ dropped out, of the remaining runners $61 \%$ dropped out.

The medical problems sustained during and after the run are presented in Table V. Two runners consulted their GP in the days after the run. One because of back pain, the other because of iliotibial tract syndrome. None were admitted to hospital or needed sick leave from work.

TABLE V

Medical problems sustained during and after the 1986 Danish national marathon championship for men.

\begin{tabular}{lrc}
\hline & $\begin{array}{c}\text { During the run } \\
(\%)\end{array}$ & $\begin{array}{c}\text { After the run } \\
(\%)\end{array}$ \\
\hline Extreme thirst & 8 & 11 \\
Gastrointestinal problems & 26 & 20 \\
Chills & 3 & 18 \\
Muscular cramps & 16 & 16 \\
Back or joint pain & 20 & 21 \\
Blisters & 16 & 26 \\
Other skin lesions & 16 & 18 \\
\hline No complaints & 44 & 49 \\
\hline
\end{tabular}

\section{DISCUSSION}

In this study the weekly mileage was twice the mileage found in previous studies concerning long distance running (Maughan et al, 1983; Jacobs et al, 1986), an illustration of the very hard work necessary to perform marathon running at elite level. Nearly all warm up before competition, but only half the runners do it before training. A possible explanation is that runners training this much and this often start at a very moderate pace, thereby including a "warm up" effect.

We found no difference between the group who used a special diet before the run and those who did not, probably because an athlete who performs such a demanding weekly training programme must use a regular diet that to nonathletes would seem special (Sharman et al, 1984).

Forty-three per cent had suffered injuries severe enough to prevent them from training. Maughan and Miller (1983) 
have in an open entry marathon found an incidence of training related injuries of $58 \%$. This difference might be due to the very thorough prophylaxis performed by the elite marathon runner concerning warming up and down, stretching, protection of the skin and feet etc. (Table II).

Several studies (Sutton et al, 1972; Wyndham et al, 1969; Phillips et al, 1983; Whitworth et al, 1983; Richards et al, 1979) of long distance running have reported dehydration as an important reason for problems during a marathon. It has been shown that weight losses of more than $8 \%$ are not uncommon among marathoners and that even partial fluid replacement reduces the medical problems (Costill, 1972). It is therefore surprising that such a large number of athletes in this group of serious runners neglect fluid intake during the run. One reason might be that some runners find it very difficult to consume large amounts of fluids during competition, another reason might be an attempt to save time.

The major medical problems during and after the run were gastrointestinal disturbances, skin lesions and pain or cramps in lower extremities. It is interesting to see that $26 \%$ had gastrointestinal problems during the competition. In a study concerning an open entry marathon the rate of gastrointestinal disturbances was only $6 \%$ (Nicholl et al, 1982). The reason for the gastrointestinal problems is most likely relative gut ischaemia (Fogoros, 1980; Sharman, 1982). The ischaemia is increased during maximal exercise and this might be the explanation for the higher rate of gastrointestinal problems in a highly competitive elite race such as this national championship.

We found no correlation between the fluid consumption on the route and the gastrointestinal disturbances. Neither did we find any correlation between the weekly training distance and the medical problems during and after the race.

\section{CONCLUSION}

From the results obtained in this study it appears that the male elite marathon runner is around 30 years, non-smoker and is $10 \%$ below ideal weight. He is training at least once a day, running a distance of $120 \mathrm{~km}$ a week. He is a fairly experienced long distance runner who is careful about using stretching and warming up and down. But it is necessary to emphasise the importance of drinking a lot of fluid along the route even in the absence of thirst. During one year every second runner sustains injuries that prevent him from training, but only very rarely prevent him from attending work. During and after a marathon competition a good $50 \%$ have various medical problems, mostly gastrointestinal disturbances, skin lesions and lower extremity pains and cramps, but very seldom serious injuries.

\section{References}

Ahlborg, B. G., Bergstrøm, J. and Brohult, J., 1976 “Human muscle glycogen content and capacity for prolonged exercises after different diets". Foersvarsmedicin 3: 85-99.

Bergstrøm, J. and Hultman, E., 1967 "A study of the glycogen metabolism during exercise in man". Scand.J.Clin.Invest. 19: 218-228.

Costill, D. L., 1972 "The physiology of marathon running". J.Am.Med.Assoc. 221 (9): 1024-1029.

Fogoros, R. N., 1980 "Runners trots: Gastrointestinal disturbances in runners". J.Am.Med.Assoc. 243: 1743-44.

Hultman, E., 1967 "Studies on muscle metabolism of glycogen and active phosphate in man with special reference to exercise and diet". Scand. Journ.Clin.Lab.Invest. 19: 94.

Ivy, J. L., Costill, D. L. and Fink, W. J., 1980 "Contribution of medicine and long chain triglyceride to energy metabolism during exercise". Int.J.Sports Med. 1: 15-20.

Jacobs, S. J. and Berson, B. L., 1986 "Injuries to runners: A study of entrants to a 10.000 meter race". Am.J.Sports Med. 14 (2): 151-155.

Maughan, R. J. and Miller, J. D. B., 1983 "Incidence of training-related injuries among marathon runners". Brit.J.Sports Med. 17 (3): 162-165.

Natvig, H., Thaysen, J. H., Christensen, L. K. and Lorenzen, I., 1980. Medicinsk Kompendium p. 1632, Arnold Busk 12th ed., Copenhagen.

Nicholl, J. P. and Williams, B. T., 1982 "Medical problems before and after a popular marathon". Brit.Med.J. 285: 1465-66.

Nicholl, J. P. and Williams, B. T., 1983 "Injuries sustained by runners during a popular marathon". Brit.J.Sports Med. 17 (1): 10-15.

Phillips, J., Horner, B. and Doorly, T., 1983 "Cerebrovascular accident in a 14-year-old marathon runner". Brit.Med.J. 286: 351-52.

Richards, R., Richards, D., Schofield, P. J. and Sutton, J. R., 1979 "Reducing the hazards in Sydney's The Sun City-to-Surf runs 1971 to 1979". Med.J.Aust. 2: 453-57.

Sharman, I. M., 1982 "Gastrointestinal disturbances in runners". Brit.J.Sports Med. 21 (3): 179.

Sherman, W. M. and Costill, D. L., 1984 "The marathon: Dietary manipulation to optimize performance". Am.J.Sports Med. 12 (1): 44-51.

Sutton, J., Coleman, M. J., Millar, A. P., Lazarus, L. and Russo, P., 1972 "The medical problems of mass participation in athletic competition". Med.J.Aust. 2: 127-33.

Whitworth, J. A. G. and Wolfman, M. J., 1983 "Fatal Heat stroke in a long distance runner". Brit.Med.J. 287: 948.

Wyndham, C. H. and Strydom, N. B., 1969 "The danger of an inadequate water intake during marathon running". S.A.Med.J. 19 July 1969: 893-896. 